\title{
Evaluation of different DNA-based fingerprinting methods for typing Photobacterium damselae ssp. piscicida
}

\author{
MONIQUE MANCUSO ${ }^{1}$, RUBÉN AVENDAÑO-HERRERA ${ }^{2}$, R ZACCONE $^{1}$, \\ ALICIA E TORANZO ${ }^{2}$ and BEATRIZ MAGARIÑOS ${ }^{2, *}$

\footnotetext{
${ }^{1}$ Istituto per l'Ambiente Marino Costiero-CNR Sezione di Messina, Italy

2 Departamento de Microbiología y Parasitología, Facultad de Biología e Instituto de Acuicultura, Universidad de Santiago de Compostela, Spain.
}

\begin{abstract}
This study evaluates the effectiveness of three different molecular techniques, repetitive extragenic palindromic PCR (REP-PCR), enterobacterial repetitive intergenic consensus sequence PCR (ERIC-PCR) and the random amplified polymorphic DNA (RAPD-PCR) for rapid typing of Photobacterium damselae ssp. piscicida strains isolated from different species of marine fish and geographic areas. The results obtained by the three methods showed that RAPD and ERIC-PCR were more discriminative for suitable rapid typing of Ph. damselae ssp. piscicida than REP-PCR. The analysis of DNA banding patterns generated by both molecular methods (RAPD and ERIC-PCR) clearly separated the strains into two main groups that strongly correlated with their geographic origin. Moreover, the REP-PCR analysis was less reproducible than the RAPD and ERIC-PCR methods and does not allow the establishment of genetic groups. RAPD and ERICPCR constitute valuable tools for molecular typing of Ph. damselae ssp. piscicida strains, which can be used in epidemiological studies of photobacteriosis infections.
\end{abstract}

Key terms: Photobacterium damselae ssp. piscicida, RAPD, ERIC-PCR, REP-PCR.

\section{INTRODUCTION}

Photobacterium damselae ssp. piscicida, previously known as Pasteurella piscicida, is the etiological agent of fish photobacteriosis or pasteurellosis, which is one of the most important diseases in Japan, affecting mainly yellowtail (Seriola quinqueradiata). From 1990 it has caused economic losses in the marine culture of gilthead sea bream (Sparus aurata), sea bass (Dicentrarchus labrax) and sole (Solea solea and Solea senegalensis) in the Mediterranean European countries and hybrid striped bass (Morone saxatilis x $M$. chrysops) in USA (Toranzo et al., 2005).

Although this pathogen is biochemically and serologically homogeneous regardless of the geographic origin and source of isolation (Magariños et al., 1996;
Bakopoulos et al., 1997), DNA fingerprinting methods such as rRNA gene restriction analysis (ribotyping) (Magariños et al., 1997), amplified fragment length polymorphism (AFLP) (Thyssen et al., 2000; Kvitt et al., 2002) and random amplified polymorphic DNA (RAPD) (Magariños et al., 2000; 2003; Hawke et al., 2003; Dalla Valle et al., 2002) have been described as powerful tools to discriminate European strains from Japanese and USA isolates.

In recent years, the development of new molecular techniques has progressed rapidly. Therefore, PCR amplification with primers specific to the repetitive genetic element REP (repetitive extragenic palindromic) and ERIC (enterobacterial repetitive intergenic consensus) have been frequently used for genomic fingerprinting 
of Gram-negative bacteria, since they are fast and simple. These repetitive elements, located in the intergenic regions of many bacteria genomes, are considered to be highly conserved (Stern et al., 1984; Hulton et al., 1991; Martin et al., 1992) and, due to this, they are useful for elucidating relationships within and among bacterial species.

The main aim of this study was to compare three PCR-based techniques for the analysis of genetic variability within Ph. damselae ssp. piscicida strains isolated from different host and geographical regions of the world, and therefore, to establish the DNA fingerprinting of this pathogen as well as to evaluate the applicability of these techniques in epidemiological studies.

\section{MATERIALS AND METHODS}

\section{Bacterial strains}

A total of $26 P h$. damselae ssp. piscicida strains were included in this study. Their sources of isolation and geographic origins are listed in Table 1. The identity of each isolate was confirmed as $P h$. damselae ssp. piscicida with standard phenotypical procedures (Magariños et al., 1992), and using the PCR-based analysis described by Osorio et al., (1999). For all experiments, the strains were routinely grown aerobically on Tryptic Soy Agar (TSA; Oxoid Ltd) supplemented with $1 \%$ (wt/vol) $\mathrm{NaCl}$ and incubated at $24^{\circ} \mathrm{C}$ for $24-48$ h. Stock cultures were maintained frozen at $-80^{\circ} \mathrm{C}$ in Criobille tubes (AES Lab).

\section{DNA extraction}

Chromosomal DNA was extracted using InstaGene Matrix (Bio-Rad) following the manufacturer's recommendations. Briefly, Ph. damselae ssp. piscicida colonies were scraped off agar plates, suspended in $1 \mathrm{ml}$ of sterile water and centrifuged at 12,000 $\mathrm{xg}$ for $1 \mathrm{~min}$. After the supernatants were removed, the pellets were resuspended in $200 \mu l$ of InstaGene Matrix and incubated at $56^{\circ} \mathrm{C}$ for $30 \mathrm{~min}$. Then, the suspensions were mixed at high speed for $10 \mathrm{~s}$ and boiled in a water bath for $8 \mathrm{~min}$. The lysates were mixed again at high speed and spun at $12,000 \mathrm{xg}$ for $3 \mathrm{~min}$. The concentration and quality of each DNA sample was examined spectrophotometrically at $260 \mathrm{~nm}$ and adjusted to a concentration of 20-30 ng $\mu l^{-1}$. All DNAs were maintained at $-20^{\circ} \mathrm{C}$ until they were used for PCR reactions. One microliter of each DNA solution was used in the respective amplification reaction.

\section{ERIC-PCR typing}

The ERIC-PCR amplifications were performed with the commercial kit ReadyTo-Go ${ }^{\mathrm{TM}}$ PCR beads (Amersham Pharmacia Biotech), which included all the reagents needed for the PCR reactions (buffer, nucleotides and Taq DNA polymerase), with the exception of the specific primers and DNA template. A pair of 22-mer primers (Sigma): ERIC 1 (5'-ATG TAA GCT CCT GGG GAT TCA C-3') and ERIC 2 (5'-AAG TAA GTG ACT GGG GTG AGC G-3') were used as previously reported by Versalovich et al. (1991). Reactions were carried out simultaneously in a $\mathrm{T}$ Gradient Thermocycler (Biometra) and Mastercycler personal (Eppendorf) equipment using an initial denaturation step at $95^{\circ} \mathrm{C}$ for $5 \mathrm{~min}$ followed by 35 cycles of denaturation $\left(92^{\circ} \mathrm{C}\right.$ for $\left.45 \mathrm{~s}\right)$, annealing $\left(52^{\circ} \mathrm{C}\right.$ for $\left.1 \mathrm{~min}\right)$, and extension $\left(70^{\circ} \mathrm{C}\right.$ for $10 \mathrm{~min})$, with a final extension step at $70^{\circ} \mathrm{C}$ for $20 \mathrm{~min}$. Negative controls, consisting of the same reaction mixture but with sterile distilled water instead of template DNA, were included in each batch of PCR reaction.

\section{REP-PCR typing}

The same Ready-To-Go ${ }^{\text {TM }}$ PCR beads were employed for REP-PCR amplifications using the following 18-mer primers (Sigma): REP 1D (5' -NNN RCG YCG NCA TCM GGC-3' ) and REP 2D (5'-RCG YCT TAT CMG GCC TAC-3'), where $\mathrm{M}$ is $\mathrm{A}$ or $\mathrm{C}, \mathrm{R}$ is $\mathrm{A}$ or $\mathrm{G}, \mathrm{Y}$ is $\mathrm{C}$ or $\mathrm{T}$ and $\mathrm{N}$ is any nucleotide (Stern et al. 1984). PCRs were performed in $25 \mu \mathrm{l}$ reaction mixture containing the same components as the ERIC-PCR mixture 
except that here REP primers were used. Reactions were performed using simultaneously a $\mathrm{T}$ Gradient Thermocycler and Mastercycler personal instrument. The programme consisted in an initial denaturation at $95^{\circ} \mathrm{C}$ for $7 \mathrm{~min}$ followed by
35 cycles of denaturation at $92^{\circ} \mathrm{C}$ for $45 \mathrm{~s}$, annealing at $40^{\circ} \mathrm{C}$ for $1 \mathrm{~min}$ and elongation at $72^{\circ} \mathrm{C}$ for 8 min with a final extension step at $72^{\circ} \mathrm{C}$ for $15 \mathrm{~min}$. As reported above, negative controls were included in each PCR-reaction.

TABLE 1

Origin of Photobacterium damselae ssp. piscicida strains used in this study

\begin{tabular}{|c|c|c|c|}
\hline Strain & Host species & Origin & Donor* \\
\hline $404 / 2$ & Dicentrarchus labrax & Italy & A. Manfrin \\
\hline $418 / 1$ & Dicentrarchus labrax & Italy & A. Manfrin \\
\hline 499 & Dicentrarchus labrax & Italy & A. Manfrin \\
\hline 524 & Dicentrarchus labrax & Italy & A. Manfrin \\
\hline 557 & Dicentrarchus labrax & Italy & A. Manfrin \\
\hline 349 & Dicentrarchus labrax & Italy & A. Manfrin \\
\hline 355 & Dicentrarchus labrax & Italy & A. Manfrin \\
\hline 387 & Sparus aurata & Italy & A. Manfrin \\
\hline L7C & Dicentrarchus labrax & Italy & M.Mancuso \\
\hline IT -2 & Sparus aurata & Italy & G. Giorgetti \\
\hline DI 21 & Sparus aurata & Spain & A.E. Toranzo \\
\hline B5.1 & Dicentrarchus labrax & Spain & J. J. Borrego \\
\hline $\mathrm{R}-46$ & Sparus aurata & Spain & J. J. Borrego \\
\hline DS 1.1 & Sparus aurata & Spain & CULMASUR \\
\hline 10831 & Dicentrarchus labrax & France & F. Baudin-Laurencin \\
\hline 619.1 & Sparus aurata & Portugal & T. Baptista \\
\hline 666.1 & Dicentrarchus labrax & Portugal & T. Baptista \\
\hline ATLIT 2 & Morone sp. & Israel & A.Colorni \\
\hline 069 A & Sparus aurata & Greece & H. Nousias \\
\hline $069 \mathrm{E}$ & Sparus aurata & Greece & H. Nousias \\
\hline ATCC 29690 & Seriola quinqueradiata & Japan & T. Kitao \\
\hline MZS 8001 & Seriola quinqueradiata & Japan & T. Kitao \\
\hline MP-7801 & Seriola quinqueradiata & Japan & T. Kitao \\
\hline EPOY-8803-II & Epinephelus akaara & Japan & K. Muroga \\
\hline P-3333 & Seriola aureovittata & Japan & R. Kusuda \\
\hline ATCC 17911 & Roccus americanus & U.S.A. & ATCC \\
\hline
\end{tabular}

* ATCC, American Type Culture Collection; T. Baptista, Unidade de Ciencias e Tecnologias dos Recursos Aquáticos, Universidade do Algarve, Portugal; F. Baudin-Laurencin, Laboratoire National de Pathologie des Animaux Aquatiques, Brest, France; J. J. Borrego, Departamento de Microbiología, Universidad de Málaga, Spain; A. Colorni, National Center for Mariculture, Eilat, Israel; CULMASUR, Cultivos Marinos del Sur S. A., Huelva, Spain; G. Giorgetti, Laboratorio di Ittiopatologia, Venice, Italy; T. Kitao, Department of Fisheries, Miyazaki University, Japan; R. Kusuda, Fish Disease Laboratory, Faculty of Agriculture, Kochi University, Japan; M. Mancuso, I.AM.C. CNR-Sezione di Messina; A. Manfrin, Istituto Zooprofilattico delle Venezie, Italy; K. Muroga, Faculty of Applied Biological Science, Hiroshima University, Japan; H. Nousias, Thalassa S. A., Hiliadou Doridos, Greece; A. E. Toranzo, Departamento de Microbiología y Parasitología, Facultad de Biología, Universidad de Santiago de Compostela, Spain. 


\section{RAPD-PCR typing}

The RAPD-PCR amplifications were performed using Ready-To-Go ${ }^{\mathrm{TM}}$ RAPD analysis beads (Amersham Pharmacia Biotech) as previously described (Magariños et al., 2000). These commercial beads have been optimised for PCR reactions and contain buffer, nucleotides and Taq DNA polymerase. The only reagents which must be added are template DNA and primers, also supplied in the kit. Two distinct random 10-mer primers (Amersham Pharmacia Biotech) were included in this study: P5 5'd[AACGCGCAAC]-3, and P6 d[CCCGTCAGCA]-3'. Each RAPD bead was resuspended in $19 \mu \mathrm{l}$ of sterile water and $1 \mu \mathrm{l}$ of purified bacterial DNA and 25 pmol of respective primer were added. The amplification protocol for RAPD analysis started with denaturation $\left(95^{\circ} \mathrm{C}\right.$ for $\left.5 \mathrm{~min}\right)$ followed by 30 cycles at $95^{\circ} \mathrm{C}$ for $1 \mathrm{~min}$ (denaturation), $35^{\circ} \mathrm{C}$ for $1 \mathrm{~min}$ (annealing) and $72^{\circ} \mathrm{C}$ for 2 min (DNA chain extension) simultaneously in a $\mathrm{T}$ Gradient Thermocycler and Mastercycler personal instrument. As negative controls, water instead of bacterial DNA was included in each reaction.

\section{Gel electrophoresis}

The RAPD, ERIC and REP-PCR products were separated using horizontal electrophoresis on a $1.5 \%$ agarose gel in TAE $1 \mathrm{x}(0.04 \mathrm{M}$ Tris, $0.0001 \mathrm{M}$ EDTA, $\mathrm{pH}$ 8.0) electrophoresis buffer, visualized using $0.06 \mu \mathrm{g} \mathrm{ml}-1$ of ethidium bromide (Bio-Rad) and photographed under UV light and computer digitised (Gel Doc 100, Bio-Rad).

In order to determine significant differences in the patterns, reproducibility of results was assessed by the repetition of RAPD, ERIC and REP-PCR assays at least three times, in which DNAs obtained in two different extractions were employed. A 502000-pb ladder (Sigma) was used as a molecular mass marker. A set of reproducible bands produced for a particular primer was defined as a pattern profile.

\section{Computer-assisted analysis of genomic fingerprints}

The genomic fingerprints obtained were compared for similarity by visual observation of the band patterns according to their presence or absence in each isolate. For the cluster analysis and comparison from all RAPD, ERIC, REP-PCR patterns, a data analysis was performed by the use of the Diversity Database software (Bio-Rad). The computed similarities among isolates were estimated by means of the Dice coefficient $\left(S_{d}\right)$ (Dice 1945) as a measure of homology, according to the equation: $S_{d}=$ $[2 A /(2 A+B+C)] \times 100$, where $A$ is the number of the matching band and $B$ and $C$ are the numbers of bands present in one strain but not in the other. Dendrograms were produced on the basis of the unweighted average pair group method (UPGMA).

\section{RESULTS AND DISCUSSION}

PCR-based typing is an effective approach in the epidemiological study of various Gram-negative bacteria. From a biochemical and serological point of view, Photobacterium damselae ssp. piscicida have been demonstrated to be identical, but genetic studies have supported the existence of genetic variability among the isolates which was associated with the geographical origin (Magariños et al. 1997; Thyssen et al. 2000).

In this paper we compared three different techniques, ERIC-PCR, REP-PCR and RAPD, frequently used as molecular tools for rapid typing of microorganisms. These assays have been reported as fast and simple to use, and the information supplied could be used in epidemiological studies of the photobacterioses.

\section{ERIC and REP fingerprinting}

Repetitive element PCR is a group of tecniques that generate DNA fingerprints which can be utilized for the discrimination of bacterial species and/or strains (Versalovic et al., 1991). In fact, REP-PCR 
and ERIC-PCR methodologies have been succesfully used for typing $V$. cholerae (Rivera et al., 1995), Vibrio parahaemolyticus (Maluping et al. 2005) and members of the family Enterobacteriaceae (Bachellier et al.. 1999). The results obtained in this work revealed that all the strains were typeable by ERIC-PCR. The fingerprinting of $P h$. damselae ssp. piscicida isolates consisted of five to seven amplification bands ranging in size from 50 to $1200 \mathrm{bp}$ (Fig. 1). The analysis of bands allowed us to identify two genomic clusters. The first group (98.5\% similarity) compiled all the Italian isolates together with these from Spain, Portugal, Greece, France, Israel and the ATCC 17911 reference strain. The second group (92\% similarity) included the Japanese strains. When the Dice coefficient was applied the similarity between the two clusters was of $82.3 \%$ (Fig. 2). The same results were obtained when ERIC-PCR was repeated at least three times demonstrating the reproducibility of the technique.

The analysis of the isolates by REP-PCR showed a similar profile among all the strains with amplification bands ranging in size from 50 to $2000 \mathrm{bp}$ and, therefore, a unique group could be established. Moreover, when this technique was repeated in different times, some of the minor light amplification bands were inconsistent making their analysis more difficult.

\section{2. $R A P D$ fingerprinting}

Similarly to that reported previously by Magariños et al. (1997) the two primers evaluated (P5 and P6) gave reproducible bands and generated patterns of amplified fragments suitable for accurate analysis. Then, they were selected for further studies with all strains. The assays were repeated at least three times for each primer tested and did not show significant differences in the profiles obtained, demonstrating that the method was reproducible.

The patterns obtained with primer 5 allowed to differentiate two genetic groups within Ph. damselae ssp. piscicida (I and II) with a similarity level of approximately $42.8 \%$ that seem to be related to the host origin of the isolates. The first group (group I) compiled all the European isolates that showed a profile of six major bands ranging from 500 to $1500 \mathrm{bp}$ in size. The other group (group II), contained the strains isolated in Japan showing a pattern with five bands ranging from 500 to $1200 \mathrm{bp}$ in size (Fig. 3 and Fig. 4). The similarity within each group was $100 \%$.

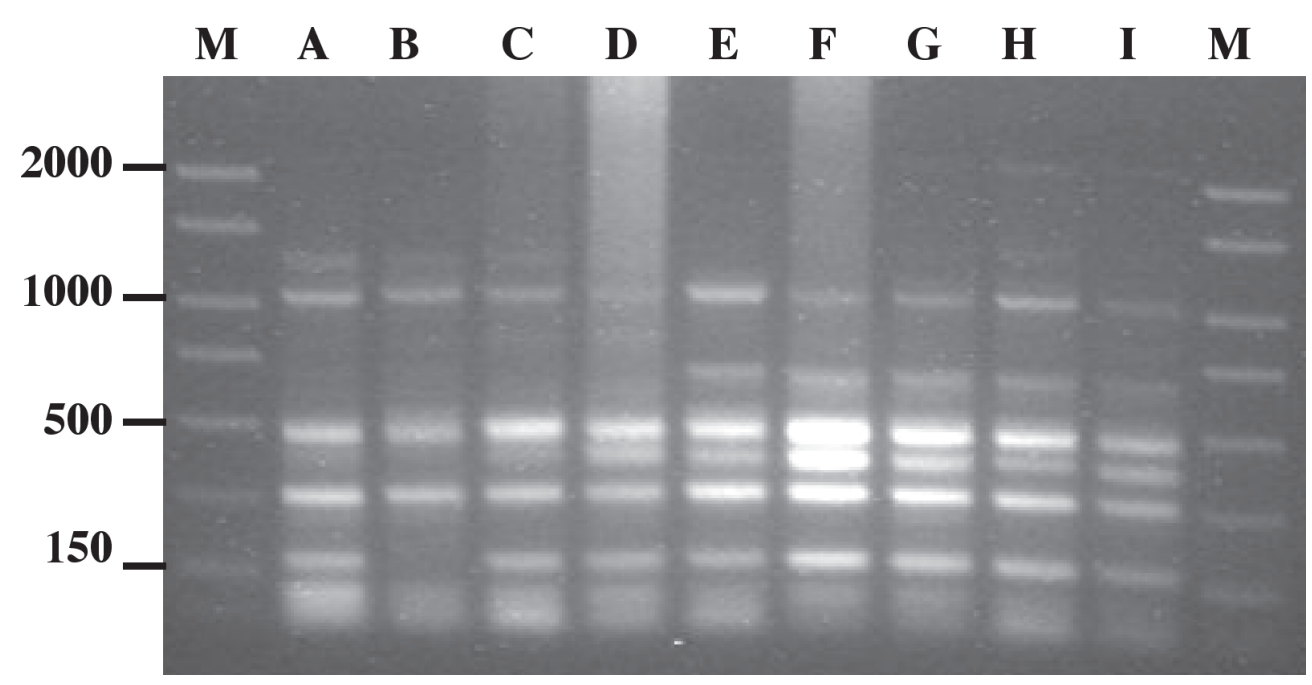

Figure 1: ERIC fingerprinting obtained for representative strains of $P h$ damselae ssp. piscicid. Lanes: M, AmpliSize Molecular Ruler (50-2000 bp; Sigma); A: ATCC- 29690; B: MP-7801; C: MZS-800; D: P-3333; E: 387; F: 1/43; G: 404/2; H: B5.1; I: 069.A. 


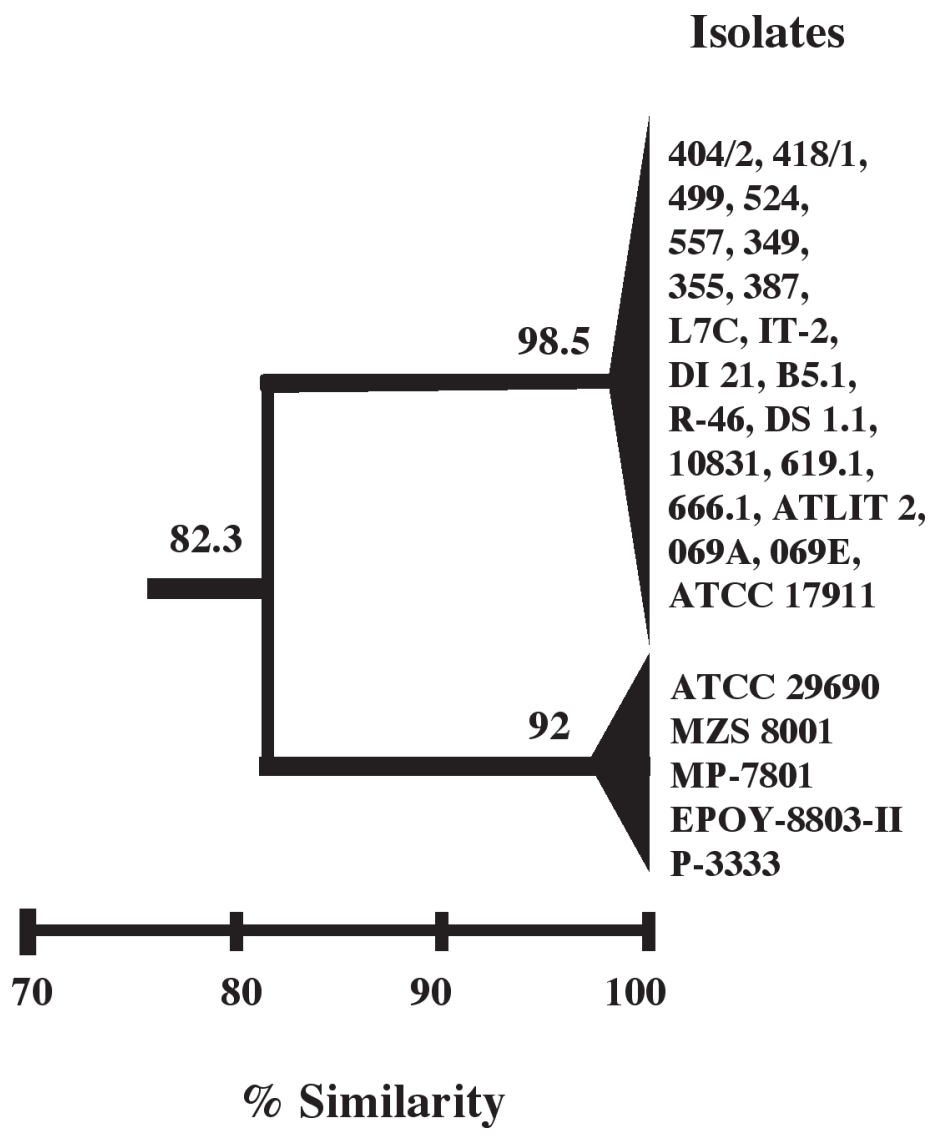

Figure 2: Dendrogram established by the Diversity Database software package (Bio-Rad) using the Dice similarity coefficient and UPGMA on the basis of the ERIC-PCR profiles of. Ph. damselae ssp. piscicida strains.

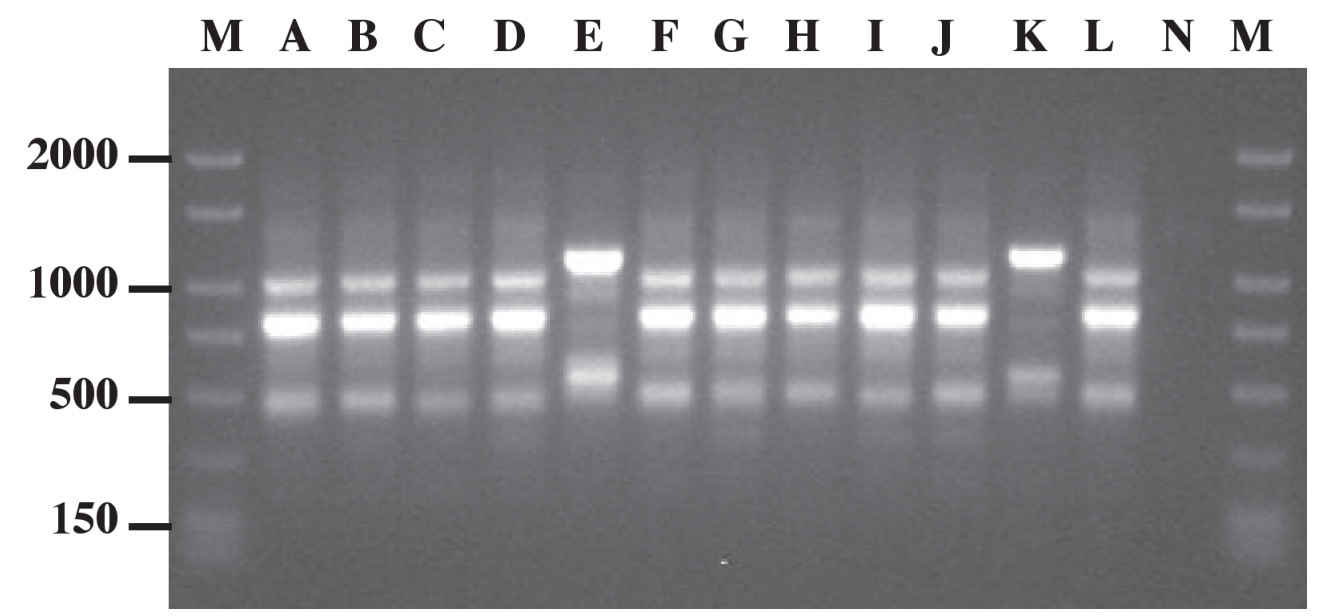

Figure 3: RAPD fingerprinting obtained for representative strains of $\mathrm{Ph}$. damselae ssp. piscida with P5. Lanes: M, AmpliSize Molecular Ruler (50-2000 bp; Sigma); A: ATCC- 17911; B: 387; C: 355; D: 404/2; E: MP-7801; F: 349; G: 557; H: 619-1; I: 540; J: 499; K: MZS-8001; L: B5.1; N: DW. Numbers on the left indicate the position of molecular size marker in bp. 


\section{Isolates}

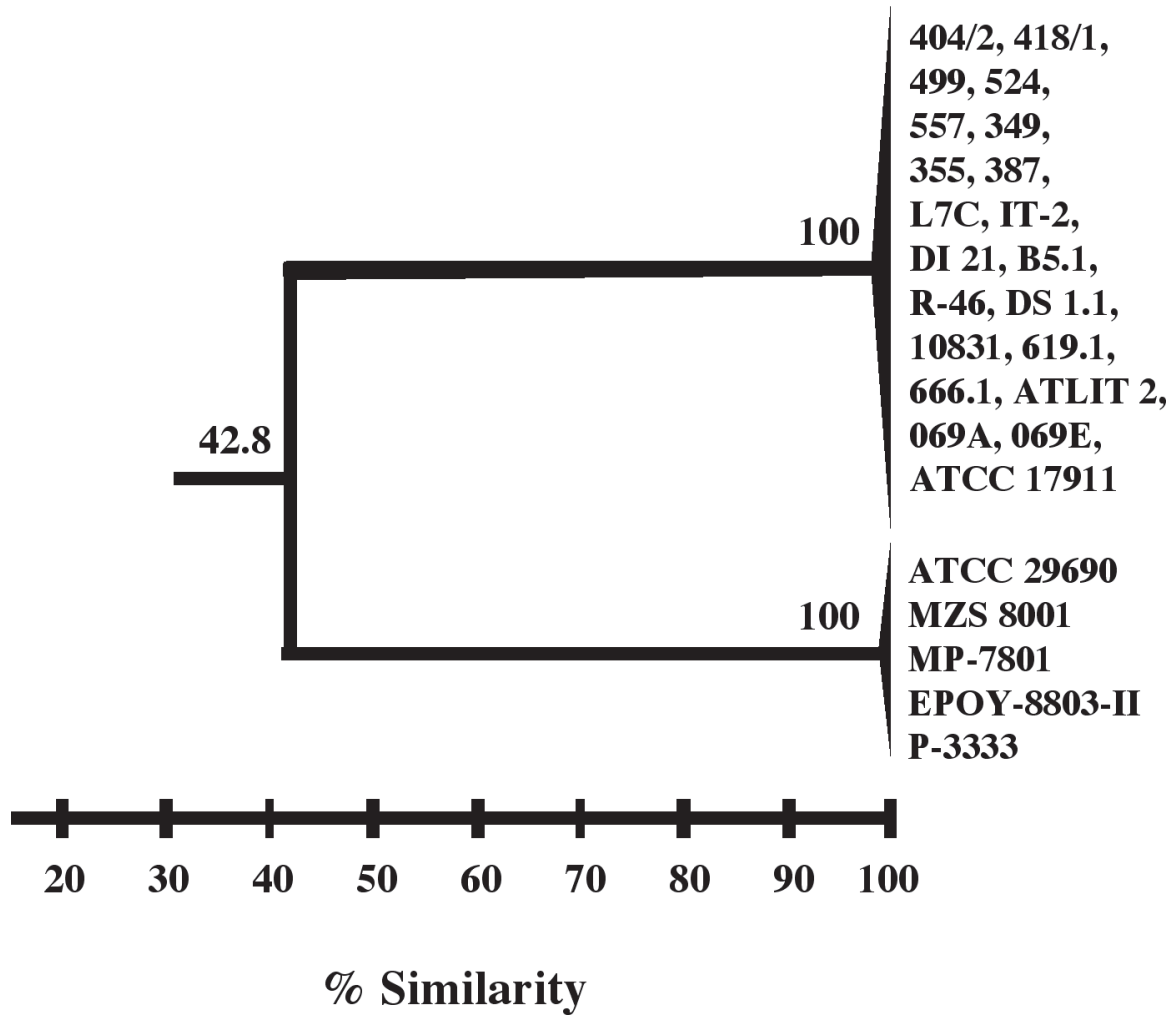

Figure 4: Dendrogram established by the Diversity Database softwear package (Bio-Rad) using the Dice similarity coefficient and UPGMA on the basis of the RAPD profiles of Ph. damselae ssp. piscicida strains obtained with primer 5.

With primer 6 a similar clustering of the isolates was obtained (data not shown), showing approximately the same Dice coefficient values within and between groups.

These results are in accordance with those previously reported by Magariños et al. (2000) in which two genetic groups were described, the European and the Japanese, and confirm the existence of two clonal lineages within this bacterial fish pathogen. However, although in that report using primer 5 two subgroups within each cluster could be differentiated, in the present study such discrimination between strains was not possible. This discrepancy could be explained because those subgroups were established based on minor amplification bands which were not amplified now or not visualized due to their very low intensity.

Although some authors reported that with the RAPD technique variability in the fingerprinting profiles can be obtained (Ellesworth et al. 1993; Oakey et al. 1996), in the present study we have found reproducible profiles for all the strains tested in the three independent RAPD-PCR reactions.

In conclusion, comparing the results obtained by the three methods it was found that, as reported by Maluping et al. (2005) for $V$. parahaemolyticus, RAPD and ERICPCR methods were more discriminative for rapid typing for Ph. damselae ssp. piscicida than REP-PCR. Therefore, both techniques constitute valuable tools for epidemiological studies of photobacteriosis infections. 


\section{ACKNOWLEDGMENTS}

The authors are grateful to the Dr. A. Manfrin (Istituto Zooprofilattico delle Venezie-PD- Italy for kindly supplying most of the Italian strains used in this work. This work was supported in part by grant AGL2004-07037 from the Ministerio de Ciencia y Tecnología (Spain). R. Avendaño-Herrera thanks a research fellowship from the CONICYT-BID programs of Chile.

\section{REFERENCES}

BACHELLIER S, CLÉMENT J-M, HOFNUNG M (1999) Short palindromic repetitive DNA elements in enterobacteria: a survey. Res Microbiol 150: 627- 639

BAKOPOULOS V, ADAMS A, RICHARDS RH (1997) Serological relationship of Photobacterium damselae subsp. piscicida isolates (the causative agent of fish pasteurellosis) determined by western blot analysis using six monoclonal antibodies. Dis Aquat Organ 28: 69-72

DALLA VALLE L, ZANELLA L, BELVEDERE $P$, COLOMBO L (2002) Use of random amplification to develop a PCR detection method for causative agent of fish pasteurellosis, Photobacterium damselae subsp. piscicida (Vibrionaceae). Aquaculture 207: 187-202

DICE LR (1945) Measures of amount of ecological association between species. Ecology 26: 297

ELLESWORTH DL, RITTENHOUSE KD, HONEYCUTT RL (1993) Artifactual variation in randomly amplified polymorphic DNA banding patterns. BioTechnique 14: 214-217

HAWKE JP, THUNE RL, COOPER RK., JUDICE E, KELLY-SMITH M (2003) Molecular and phenotypic characterization of strains of Photobacterium damselae subsp. piscicida isolated from hybrid striped bass cultured in Louisiana, USA. J Aquat Anim Health 15: 189-201

HULTON CS, HIGGINS CF, SHARP PM (1991) ERIC sequences: a novel family of repetitive elements in the genomes of Escherichia coli, Salmonella typhimurium and other enterobacteria. Mol Microbiol 5: 825-834

KVITT H, UCKO M, COLORNI A, BATARGIAS C, ZLOTKIN A, KNIBB W (2002) Photobacterium damselae ssp. piscicida: detection by direct amplification of $16 \mathrm{~S}$ rRNA gene sequences and genotypic variation as determined by amplified fragment length polymorphism (AFLP). Dis Aquat Organ 48: 187-195

MAGARIÑOS B, ROMALDE JL, BANDÍN I, FOUZ B, TORANZO AE (1992) Phenotypic, antigenic, and molecular characterization of Pasteurella piscicida strains isolated from fish. Appl Environ Microbiol 58: 3316-3322
MAGARIÑOS B, TORANZO AE, ROMALDE JL (1996) Phenotypic and pathobiological characteristics of Pasteurella piscicida. Ann Rev Fish Dis 6: 41-64

MAGARIÑOS B, OSORIO CR, TORANZO AE, ROMALDE JL (1997) Applicability of ribotyping for intraspecific classification and epidemiological studies of Photobacterium damselae subsp. piscicida. Syst Appl Microbiol 20: 634-639

MAGARIÑOS B, TORANZO AE, BARJA JL, ROMALDE JL (2000) Existence of two geographically-linked clonal lineages in the bacterial fish pathogen Photobacterium damselae subsp. piscicida evidence by random amplified polymorphic DNA analysis. Epidemiol Infect 125: 213-219

MAGARIÑOS B, ROMALDE JL, LÓPEZ-ROMALDE S, MORIÑIGO MA, TORANZO AE (2003) Pathobiological characterization of Photobacterium damselae subsp. piscicida isolated from cultured sole (Solea senegalensis). Bull Eur Ass Fish Pathol 23: 183-189

MALUPING R, RAVELO C, LAVILLA-PITOGO C, KROVACEK K, ROMALDE JL (2005) Molecular typing of Vibrio parahaemolyticus strains isolated from the Philippines by PCR-based methods. J Appl Microbiol 99: 383-391

MARTIN B, HUMBERT O, CAMARA M, GUENZI E, WALZER J, MITCHELL T, ANDREI P, PRUDHOMME M, ALLOING G, HACKENBECK R, MORRISON DA, BUOLNOIS GJ, CLAVERYS JP (1992) A highly conserved repeated DNA element located in the chromosome of Streptococcus pneumonite. Nucleic Acids Res 20: 3479-3483

OAKEY HJ, ELLIS JT, GIBSON LF (1996) Differentiation of Aeromonas genomospecies using random amplified polimorphic DNA polymerase chain reaction (RAPDPCR). J Appl Bacteriol 80: 402-410.

OSORIO CR, COLLINS MD. TORANZO AE, BARJA JL, ROMALDE JL (1999) 16S rRNA gene sequence analysis of Photobacterium damselae and nested PCR method for rapid detection of the causative agent of fish pasteurellosis. Appl. Environm Microbiol 65: 2942-2946

RIVERA IG, CHOWDHURY MAR, HUQ A, JACOBS D, MARTINS MT, COLWELL RR (1995) Enterobacterial repetitive intergenic consensus sequences and the PCR to generate fingerprints of genomic DNAs from Vibrio cholerae O1, O139 and non-O1 strains. Appl Environm Microbiol 61: 2898-2904

STERN MJ, AMES GFL, SMITH NH, ROBINSON EC, HIGGINS CF (1984) Repetitive extragenic palindromic sequences: a major component of bacteria genome. Cell 37: 1015-1026

THYSSEN A, VAN EYGEN S, HAUBEN L, GORIS J, SWINGS J, OLLEVIER F (2000) Application of AFLP for taxonomic and epidemiological studies of Photobacterium damselae subsp. piscicida. Int J Syst Evol Microbiol 50: 1013-1019

TORANZO AE, MAGARIÑOS B, ROMALDE JL (2005) A review of the main bacterial fish diseases in mariculture systems. Aquaculture 246: 37-61

VERSALOVICH J, KOEUTH T, LUPSKI JR (1991) Distribution of repetitive DNA sequences in eubacteria and application to fingerprinting of bacterial genomes. Nucleic Acids Res 19: 6823-6831. 